MA'ALIM: Jurnal Pendidikan Islam

Volume 1, Nomor 1, Juli 2020

\title{
KONSEPSI MASYARAKAT MADANI DALAM BINGKAI PENDIDIKAN ISLAM
}

\author{
Mughniatul Ilma \\ IAIN Ponorogo \\ mughniatulilma@gmail.com
}

\author{
Rifqi Nur Alfian \\ SMKN 1 Kebonsari Madiun \\ rifqinuralfian@gmail.com
}

\begin{abstract}
The challenge of globalization is increasingly rocking the social order in society. This can be a real threat to a nation if it is continuously allowed to flow without any meaningful effort. Various problems arise including moral decadence, moral degradation to the disintegration of the nation. This requires a revolution in the social system of society. Civil society as an old concept which became known as 'Islamic' with the term Civil Society became important to be made a proposal for change. Civil society is the ideal form of society that all nations aspire to. The building of civil society requires a variety of solid and resilient materials based on the foundation of religion. The key to the building is Islamic Education. Islamic education is an effort to create a superior generation that is Islamic, which in turn will unite itself to form a religious, moral, high quality and creative society in building civilization.
\end{abstract}

Keywords: Civil society, islamic education, masyarakat madani.

\begin{abstract}
Abstrak: Tantangan globalisasi semakin mengguncang tatanan sosial dalam masyarakat. Hal ini dapat menjadi ancaman yang nyata bagi suatu bangsa apabila terus menerus dibiarkan mengalir begitu saja tanpa ada usaha yang berarti. Berbagai permasalahan muncul meliputi dekadensi moral, degradasi akhlak hingga disintegrasi bangsa. Hal tersebut meniscayakan adanya revolusi dalam sistem sosial masyarakat. Civil society sebagai konsep lama yang kemudian dikenal lebih 'islami' dengan istilah Masyarakat Madani menjadi penting untuk dijadikan sebuah usulan perubahan. Masyarakat madani merupakan bentuk masyarakat yang ideal yang dicita-citakan semua bangsa. Bangunan masyarakat madani membutuhkan berbagai material yang kokoh dan tangguh yang berlandaskan pada pondasi agama. Kunci bangunan tersebut adalah Pendidikan Islam. Pendidikan Islam sebagai upaya mencetak generasi unggul yang Islami, yang nantinya akan mempersatukan diri membentuk masyarakat yang religius, bermoral, memiliki kualitas tinggi dan kreatif dalam membangun peradaban.
\end{abstract}

Kata kunci: Masyarakat Madani, Civil Society, Pendidikan Islam.

\section{PENDAHULUAN}

Masyarakat madani dapat diartikan sebagai suatu masyarakat yang beradab dalam membangun, menjalani, dan memaknai kehidupannya. Masyarakat madani sejatinya bukanlah konsep yang ekslusif dan dipandang sebagai teori kuno. Ia merupakan konsep yang senantiasa hidup dan dapat berkembang dalam setiap ruang dan waktu. Masyarakat madani merupakan 
MA'ALIM: Jurnal Pendidikan Islam

Volume 1, Nomor 1, Juli 2020

konstruksi bahasa yang "Islami" yang mengacu pada kata al-din, yang umumnya diterjemahkan sebagai agama, berkaitan dengan makna al-tamaddun atau peradaban. Keduanya menyatu ke dalam pengertian al-madinah yang artinya kota. Dengan demikian, maka terjemahan masyarakat madani mengandung tiga hal, yakni agama, peradaban dan perkotaan. Di sini agama merupakan sumber, peradaban adalah prosesnya, dan masyarakat kota adalah hasilnya. ${ }^{1}$

Berbicara mengenai masyarakat madani di zaman modern seperti saat ini adalah merupakan satu kebutuhan yang tidak bisa ditawar lagi untuk segera direalisasikan. Situasi semacam ini disebabkan oleh masyarakat modern yang beraneka ragam yang sarat akan kepentingan pribadi maupun golongan. Oleh karena itu, menurut Thohir Luth, masyarakat madani merupakan solusi damai dalam perbedaan. ${ }^{2}$ Dengan kata lain tegaknya nilai-nilai hubungan sosial yang luhur, seperti toleransi, dan pluralisme merupakan kelanjutan dari tegaknya nilai-nilai keadaban. Dengan penghargaan, kesediaan memandang yang lain dengan penghargaan, betapapun perbedaan yang ada tanpa saling memaksakan kehendak, pendapat atau pandangan sendiri. ${ }^{3}$

Untuk mewujudkan sistem sosial masyarakat madani tentu harus diawali dengan membangun kualitas individu khususnya dan masyarakat pada umumnya. Salah satu upayanya adalah dengan melalui pendidikan. Pendidikan menjadi mutlak diperlukan dalam rangka untuk menganalisa dan membentuk manusia sebagai individu maupun sebagai masyarakat. ${ }^{4}$ Pendidikan merupakan rancangan kegiatan yang paling banyak berpengaruh terhadap perubahan perilaku seseorang dan suatu masyarakat. Sebagaimana apa yang pernah dikemukakan oleh Jalaluddin Rahmat bahwasannya perubahan sosial hanya memungkinkan terjadi manakala telah didahului oleh perubahan pola pikir masyarakat. Pendidikan merupakan model rekayasa sosial yang paling efektif untuk menyiapkan suatu bentuk masyarakat masa depan. ${ }^{5}$

Secara substansial, masyarakat madani meniscayakan terciptanya kehidupan masyarakat yang penuh dengan kecerdasan, kreatifitas (life skill), keadaban, kejujuran, keadilan, keterbukaan,

\footnotetext{
${ }^{1}$ M. Dawam Raharjo, Masyarakat Madani: Agama, Kelas Menengah dan Perubahan Sosial, Cet. I, (Jakarta: Pustaka LP3ES, 1999), hal. 146.

2 Thohir Luth, Masyarakat Madani Solusi Damai Dalam Perbedaan, (Jakarta: Mediacita, 2002) hal. 32.

${ }^{3}$ Nurcholis Madjid, “Menuju Masyarakat Madani”dalam Jurnal Kebudayaan dan Peradaban Ulumul Qur'an, No. 2/VII/1996, hal. 11.

${ }^{4}$ Ahmad Busyairi dan Azharuddin Sahil, Tantangan Pendidikan Islam, (Yogyakarta: LPM UII, 1987), hal. 119.

${ }^{5}$ Irfan Charis dan Mohamad Nuryansah, “Pendidikan Islam Dalam Masyarakat Madani Indonesia”, Jurnal Mudarrisa: Jurnal Kajian Pendidikan Islam, Vol. 7 No. 2 Desember 2015, hal. 233.
} 
MA'ALIM: Jurnal Pendidikan Islam

Volume 1, Nomor 1, Juli 2020

dan penuh dengan nilai-nilai yang bersumber religuisitas. Zamakhasyari Dhofier mengartikan tamaddun sebagai masyarakat yang maju, stabil, mandiri, demokratis, adil dan kompetitif, dan mengandalakan kualitas pendidikan yang tinggi dalam berbagai jenis keilmuan dan keterampilan. ${ }^{6}$ Oleh karena itu, dalam membangun masyarakat madani diperlukan sebuah proses pendidikan yang panjang dan berkesinambungan. Salah satu alternatif yang dapat ditawarkan adalah dengan cara membumikan Pendidikan Islam dalam rangka membentuk manusia sebagai individu yang akan melahirkan sebuah komunitas masyarakat yang dicita-citakan, dengan memperhatikan empat pilar utama pendidikan yaitu learning to know, learning to do, learning to be, learning to life together.

Secara sederhana pendidikan Islam dapat diartikan sebagai usaha sadar yang dilakukan secara sistematik untuk membentuk masyarakat didik sesuai dengan tuntutan Islam. ${ }^{7}$ Hakekat Pendidikan Islam merupakan proses transformasi ajaran dan nilai-nilai Islam yang berfungsi sebagai rahmatan lil 'alamin. Dalam perspektif inilah yang pada akhirnya pendidikan Islam penulis anggap memiliki potensi besar dalam kerangka membentuk masyarakat madani.

\section{MASYARAKAT MADANI: SEBUAH EKSPEKTASI MASA DEPAN}

Tak dapat dipungkiri bahwa globalisasi memiliki dampak yang besar terhadap sistem sosial dalam masyarakat. Pergeseran nilai moral ke arah degradasi semakin terlihat dalam kehidupan sosial masyarakat. Krisis multidimensional di segala bidang pun tidak dapat terhindarkan. Oleh sebab itu, perubahan terhadap masyarakat adalah hal yang mutlak harus dilakukan. Terwujudnya suatu masyarakat baru menjadi sebuah keniscayaan. Masyarakat baru yang mengharapkan terwujudnya kemajuan, kesejahteraan, kebahagiaan, keterbukaan, keadilan, saling menghormati dan menghargai, menegakkan hukum dengan adil, menghargai hak asasi manusia, modern dan ingin meninggalkan pola-pola kehidupan masyarakat yang negatif.

Secara umum, masyarakat madani merupakan masyarakat yang dicita-citakan semua bangsa. Masyarakat madani adalah suatu tatanan masyarakat sipil yang mandiri dan demokratis, religius dan beradab, menjunjung nilai-nilai kemanusiaan, serta masyarakat yang maju dalam penguasaan ilmu pengetahuan dan teknologi. Di Indonesia, istilah masyarakat madani mulai digaungkan menjelang beberapa tahun terakhir masa kekuasaan otoriter orde baru. Hingga

\footnotetext{
${ }^{6}$ Ismail SM dan Abdullah Mukti, Pendidikan Islam, Demokratisasi dan Masyarakat Madani, (Yogyakarta: Pustaka Pelajar, 2000), hal. 150.

${ }^{7}$ Abudin Nata, Managemen Pendidikan: Mengatasi Kelemahan Pendidikan Islam, (Jakarta: Prenada Media, 2003), hal. 129.
} 
MA'ALIM: Jurnal Pendidikan Islam

Volume 1, Nomor 1, Juli 2020

akhirnya rezim tersebut tumbang, konsep masyarakat madani semakin sering disebut, terutama oleh para intelektual modernis. Kemunculan wacana masyarakat madani tersebut merupakan refleksi dari keinginan untuk membuat suatu sistem sosial yang baru, yang dianggap akan membawa perubahan yang lebih baik dalam kehidupan masyarakat bangsa Indonesia pasca orde baru. Konsep masyarakat madani semula dimunculkan sebagai jawaban atas usulan untuk meletakkan peran agama ke dalam suatu masyarakat multikultural, yang merupakan produk dari proses demokratisasi yang sedang berlangsung terus menerus yang kemudian memunculkan ide pluralistik dan implikasinya terhadap kesetaraan hak individual.

Adapun ciri unggul sistem sosial madani versi masyarakat madinah bentukan Rasulullah yakni kesetaraan, istiqomah, mengutamakan partisipasi, dan demokratisasi. Jadi, masyarakat madani pada dasarnya adalah sebuah komunitas dimana keadilan dan kesetaraan menjadi fundamennya. Muara dari pada itu adalah pada demokratisasi, yang dibentuk sebagai akibat adanya pertisipasi nyata anggota kelompok masyarakat. ${ }^{8}$ Di sisi lain, Azyumardi Azra memberi penegasan bahwa masyarakat madani mempunyai arti lebih dari sekedar gerakan pro-demokrasi, karena ia juga mengacu pada pembentukan masyarakat berkualitas dan bertamadun (civility). Lebih lanjut, Nurcholish Nadjid menjelaskan, makna masyarakat madani berakar dari kata "civility" mengandung makna toleransi, kesediaan pribadi-pribadi untuk menerima berbagai macam pandangan politik dan tingkah laku sosial.

Dari berbagai pemaparan di atas, dapat disimpulkan bahwa masyarakat madani memiliki berbagai karakteristik di dalamnya yang tidak dapat terabaikan antara satu dengan yang lain. Karakteristik masyarakat madani tersebut antara lain:

1. Adanya ruang publik (publik spere) yang bebas bagi masyarakat (warga negara) untuk menyalurkan gagasan dan pendapat, kreatifitas berkarya baik melalui individu-individu, perkumpulan-perkumpulan maupun melalui media informasi.

2. Adanya pola kehidupan yang demokratis, artinya warga dalam berperilaku selalu santun melalui interaksi-interaksi sosial tanpa ada perasaan terikat dan tertekanan dari pihak manapun, tetapi perilaku itu muncul berangkat dari kesadaran diri sendiri yang tinggi.

3. Bersikap toleran dalam kehidupan masyarakat yang penuh dengan keanekaragaman pola aktivitas kehidupan.

\footnotetext{
${ }^{8}$ Dede Rosyada, et al. Pendidikan Kewarganegaraan (Civic Education), Demokrasi, Hak Asasi Manusia dan Masyarakat Madani, (Jakarta: ICCE UIN Syarif Hidayatullah dan Prenada Media, 2003), hal. 250.
} 
MA'ALIM: Jurnal Pendidikan Islam

Volume 1, Nomor 1, Juli 2020

4. Selalu mencerminkan sikap yang pluralisme dengan mengedepankan perilaku yang berkeadaban, sehingga tercipta suasana kehidupan yang aman dan damai.

5. Menjunjung tinggi nilai-nilai HAM dan nilai-nilai keadilan, guna terciptanya keseimbangan dalam kehidupan bermasyarakat.

\section{MASYARAKAT MADANI: SAMAKAH DENGAN CIVIL SOCIETY?}

Masyarakat madani seringkali disepadankan dengan istilah civil society. Civil society secara harfiah adalah terjemahan dari istilah Latin, Societas Civilis. Menurut Cicero (106-43 SM) Masyarakat sipil disebutnya sebagai sebuah masyarakat politik (Political Society) yang memiliki kode hukum sebagai pengaturan hidup. ${ }^{9}$ Jadi, secara semantik dapat disimpulkan bahwa keduanya secara parsial substantif memiliki kesamaan dan keduanya sangat relevan sebagai bahan kajian dalam upaya mencari paradigma masyarakat baru yang plural, demokratis, damai, saling menghormati dengan landasan hukum, hak dan tanggung jawab bersama sehingga terbentuk masyarakat yang tamaddun atau berperadaban. Namun secara pragmatik, sebenarnya keduanya memiliki perbedaan jika dilihat dari konteks historis. Keduanya lahir dari dua sistem budaya yang berbeda. Civil society merujuk pada tradisi Barat non-Islam. Civil society merupakan produk modernitas yang berasal dari gerakan masyarakat sekuler yang mengesampingkan Tuhan serta mengedepankan rasional, sehingga civil society mempunyai moral-transendental yang rapuh. Sedangkan masyarakat madani lahir dalam tradisi Arab-Islam, ia dibentuk melalui petunjuk Tuhan, patuh terhadap agama serta beradab, bukan hanya mengedepankan rasional tetapi tetap menyeimbangkan antara dunia dan akhirat, sehingga dapat disimpulkan bahwa masyarakat madani adalah istilah yang dilahirkan untuk menerjemahkan konsep di luar menjadi "Islami". Karena alasan inilah, A. Syafi'i Ma'arif mendefinisikan masyarakat madani sebagai sebuah masyarakat yang terbuka, egaliter, dan toleran atas landasan nilai-nilai etik-moral transendental yang bersumber dari wahyu Allah. ${ }^{10}$

Masyarakat madani dapat dikatakan sebagai dialog dialektik antara Islam dan Barat (modernitas) yang bersifat aktif. Masyarakat madani kadang dipahami sebagai masyarakat sipil karena diterjemahkan dari konsep civil society yang lahir di Barat pada abad ke-18 dengan tokohnya John Locke atau Montesquieu. Meskipun sebelumnya pada zaman Yunani Kuno juga

${ }^{9}$ M. Dawam Raharjo, Sejarah Agama dan Masyarakat Madani dalam Membongkar “Mitos” Masyarakat Madani, (Pustaka Pelajar, Yogyakarta, 2001), hal. 18

${ }^{10}$ A. Syafi'i Ma'arif, Mencari Autentisitas Dalam Kegalauan, (Yogyakarta: PSAP, 2004), hal. 84. 
MA'ALIM: Jurnal Pendidikan Islam

Volume 1, Nomor 1, Juli 2020

sudah dikenal Societas Civilis yang dinyatakan oleh Cicero, namun pengertiannya lebih identik dengan Negara. Munculnya konsep masyarakat madani menunjukkan bahwa intelektual muslim mampu menginterprestasikan ajaran Islam dalam kehidupan modern, persisnya mengawinkan ajaran Islam dengan konsep civil society yang lahir di barat pada abad ke-18. Berdasarkan projecting back theory (melihat sejarah awal islam sebagai patokan), ${ }^{11}$ Civil society yang lahir di Barat diislamkan menjadi masyarakat madani, yaitu masyarakat kota Madinah bentukan Nabi Muhammad SAW yang merupakan proto-masyarakat modern. Mereka mengambil contoh dari data historis Islam yang secara kualitatif dapat dibandingkan dengan masyarakat ideal dalam konsep civil society dan melakukan reinterpretasi terhadap konsep tersebut agar dapat mengikuti perkembangan zaman menuju ke arah yang lebih baik.

Begitu pula dengan konsep civil society, ternyata sebelumnya Barat telah melakukan studi perbandingan dengan peradaban Islam ketika hendak merumuskan istilah tersebut. Pada saat itu, Barat sedang dalam cengkraman pemerintahan otoriter dan menilai sistem pemerintahan Nabi Muhammad SAW adalah sangat baik. Pengaruh Islam dalam civil society tersebut telah dijelaskan oleh C.G. Weeramantry dan M. Hidayatullah dalam bukunya Islamic Jurisprudence: An Intenational Perspective, terbitan Macmillah Press (1988). Menurutnya, pemikiran John Locke dan J.J. Rousseau tentang teori kedaulatan (sovereignty) mendapatkan pengaruh dari pemikiran Islam. Locke ketika menjadi mahasiswa Oxford University sangat frustasi dengan disiplin keilmuannya, dan lebih tertarik mengikuti ceramah dan kuliah Edward Pococke, seorang professor dalam studi tentang Arab. Sehingga hal tersebut mempengaruhi pemikiran Locke mengenai pemerintahan, kekuasaan, dan kebebasan individu. Demikian halnya, pemikiran J.J. Rousseau dalam The Sosial Contract yang juga banyak dipengaruhi oleh Islam. Bahkan dia secara jelas menyebut: "Mohamet had very sound opinions, taking care to give unity to his political system, and for as long as the form of his government endured under the caliphs who succeeded him, the

${ }^{11}$ Projecting back theory merupakan teori yang berangkat dari sebuah hadist yang mengatakan:

خير القرون قرنى ثم الذى يلونهم ثم الذى يلونهم (رو اه الترمذى) Maksud dari hadits tersebut yakni dalam menetapkan ukuran baik atau buruknya perilaku harus dengan merujuk pada kejadian yang terdapat dalam khazanah sejarah masa awal Islam dan bila tidak ditemukan maka dicari pada sumber normatif al-Qur'an dan Hadist. Lihat Thoha Hamim, Islam dan Civil Society (Masyarakat Madani), (Yogyakarta: Pustaka Pelajar, 2000), hal. 115-127. 
MA'ALIM: Jurnal Pendidikan Islam

Volume 1, Nomor 1, Juli 2020

government was undivided and, to that extent, good". ${ }^{12}$ Corak pemikiran Islam juga terlihat dalam buku Persian Letters karya Montesquieu, yang kemudian diteruskan dalam buku berikutnya The Spirit of the Laws. Dalam buku tersebut tertulis "indeed there are many specific references to the Qur'an and to the Islamic law in the writing of Montesquieu". ${ }^{13}$

Istilah masyarakat madani sebagai terjemahan dari civil society baru dikenal di Indonesia pada tahun 1995, yaitu ketika Dato Seri Anwar Ibrahim, Menteri Keuangan dan Timbalan Perdana Menteri Malaysia, pada waktu itu menyampaikan ceramahnya yang berjudul "Islam dan Pembentukan Masyarakat Madani” pada Simposium Nasional dalam rangka Forum Ilmiah Festival Istiqlal, 26 September 1995. ${ }^{14}$ Istilah itu diterjemahkan dari bahasa Arab mujtama' madani, yang diperkenalkan oleh Prof. Naquib Attas, seorang ahli sejarah dan peradaban Islam dari Malaysia dan pendiri ISTAC. ${ }^{15}$ Dalam ceramah itu, Dato Seri Anwar Ibrahim menyatakan bahwa masyarakat madani ialah sistem sosial yang subur yang diasaskan pada prinsip moral yang menjamin keseimbangan antara kebebasan perorangan dengan kestabilan masyarakat. Masyarakat mendorong daya usaha serta inisiatif individu baik dari segi pemikiran, seni, pelaksanaan pemerintahan mengikuti undang-undang dan bukan nafsu atau keinginan individu menjadikan keterdugaan atau predictability serta ketulusan atau transparency sistem. ${ }^{16}$

Selanjutnya, konsep masyarakat madani dipopulerkan oleh salah seorang intelektual muslim Indonesia, Nur Cholis Madjid dalam Makalah Pidato Halal Bihalal KAHMI (Jakarta, 11 Syawwal 1419 / 28 Januari 1999) yang berjudul "Meneruskan Agenda Reformasi untuk Demokrasi dengan Landasan Jiwa Masyarakat madani; Masalah Pluralisme dan Toleransi." Konsep yang sama juga dipaparkan oleh para intelektual modernis, seperti M. Dawam Raharjo, Abdurrahman Wahid, AS. Hikam, Mansour Fakih, dll. Sekalipun mereka, dalam beberapa hal, berbeda dalam memaknai masyarakat madani atau civil society, namun mereka memiliki keprihatinan yang sama, terutama dalam persoalan kekuasaan pemerintah yang terlalu kuat pada

12 J.J. Rousseau, The Social Contract, translt. M. Cranston, Book IV (Harmondsworth: Penguin, 1968), hal. 179, dalam Farhad Malekian, Corpus Juris of Islamic International Criminal Justice, (Ukraina: Cambridge Scholars Publishing, 2017), hal. 74.

${ }^{13}$ A. Qodri Abdillah Azizi, "Masyarakat madani Antara Cita dan Fakta: Kajian Historis-Normatif" dalam Ismail SM dan Abdullah Mukti, Pendidikan Islam, Demokratisasi dan Masyarakat Madani, (Yogyakarta: Pustaka Pelajar, 2000), hal. 94.

${ }^{14}$ Thoha Hamim, Islam dan Civil Society (Masyarakat Madani), (Yogyakarta: Pustaka Pelajar, 2000), hal. 115.

${ }^{15}$ Ismail SM dan Abdullah Mukti, Pendidikan Islam, Demokratisasi, dan ..., hal. 180.

${ }^{16}$ M. Dawam Rahardjo, Masyarakat Madani di Indonesia Sebuah Penjajakan Awal, Jurnal Pemikiran Islam Paramadina, Jakarta, Vol. I No. 2, 1999, hal. 23. 
MA'ALIM: Jurnal Pendidikan Islam

Volume 1, Nomor 1, Juli 2020

era orde baru. Mereka umumnya menjadikan Amerika Serikat sebagai model dari bentukan civil society. Di Amerika kekuasaan negara sangat terbatas dan tidak bisa mengintervensi hak-hak individu (biasa disebut dengan small stateness), namun sangat kuat dalam bidang pelaksanaan hukum. Sedangkan di Indonesia, yang terjadi adalah sebaliknya. ${ }^{17}$

\section{PARADIGMA MASYARAKAT MADANI DALAM SEJARAH PERADABAN ISLAM}

Secara eksplisit, al-Qur'an telah memberikan petunjuk mengenai ciri-ciri dan kualitas suatu masyarakat yang baik. Namun, secara konseptual, hal tersebut masih memerlukan upaya interpretasi dan pengembangan pemikiran. Peluang tersebut sangat memungkinkan bagi seorang pemikir muslim untuk merekonstruksi suatu gambaran masyarakat yang ideal berdasarkan petunjuk Al Qur'an. Salah satunya yang dilakukan oleh al-Farabi, ${ }^{18}$ seorang filsuf dan ulama muslim kenamaan di abad pertengahan. Beliau membangun konsep tentang al-Madinah alFadhilah yaitu sebuah Negara yang mewujudkan segala keutamaan hidup atas dasar ketuhanan Yang Maha Esa. ${ }^{19}$

Berdasarkan konsep yang dikemukakan oleh al-Farabi tentang Al-Madinah Al-Fadhilah yang lebih di kenal oleh para cendikiawan muslim dengan sebutan Baldah Thayyibah yang sempat berkembang menjadi mitos. Itulah konsep yang di kenal pada saat sebelum munculnya konsep Masyarakat Madani. ${ }^{20}$ Jika melihat pada konsep Baldah Thayyibah, sebenarnya ada dua peradaban yang terdokumentasi sebagai masyarakat Baldah Thayyibah atau Masyarakat Madani. Pertama, Masyarakat negeri Saba', yaitu masyarakat pada masa Nabi Sulaiman AS. ${ }^{21}$ Keadaan masyarakat Saba’ yang diceritakan dalam al-Quran itu mendiami negeri yang baik, subur, dan nyaman. Di

${ }^{17}$ Muhammad Muslih, “Wacana Masyarakat Madani: Dialektika Islam Dengan Problem Kebangsaan”, Jurnal Tsaqafah Vol. 6 No. I April 2010, hal. 130-131.

18 Al-Farabi adalah penafsir filsafat Plato dan filsafat Aristoteles. Sebagaimana seorang pemikir, ia digolongkan ke dalam aliran Neo-Platonis. Oleh karena itu, kemungkinan besar konsepnya mendapat ilham dari gagasan Plato yang ditulis dalam bukunya yang terkenal, Republic, yang merupakan konseptualisasi model city-state atau Negara Kota pada zaman Yunani yang masih relevan pada masa abad pertengahan di dunia Islam. Lihat M. Dawam Raharjo, Masyarakat Madani: Agama, Kelas Menengah dan Perubahan Sosial, Cet. I, (Jakarta: Pustaka LP3ES, 1999), hal. 81.

${ }^{19}$ M. Dawam Raharjo, Masyarakat Madani: Agama, Kelas Menengah dan..., hal. 79.

${ }^{20}$ Ibid., hal. 81.

${ }^{21}$ Allah SWT memberikan gambaran bahwa Masyarakat Saba merupakan masyarakat madani dengan firmanNya dalam Q.S. Saba' ayat 15 yang artinya: "Sesungguhnya bagi kaum Saba' ada tanda (kekuasaan Tuhan) di tempat kediaman mereka yaitu dua buah kebun di sebelah kanan dan di sebelah kiri. (kepada mereka dikatakan): "Makanlah olehmu dari rezki yang (dianugerahkan) Tuhanmu dan bersyukurlah kamu kepada-Nya. (Negerimu) adalah negeri yang baik dan (Tuhanmu) adalah Tuhan yang Maha Pengampun”. 
MA'ALIM: Jurnal Pendidikan Islam

Volume 1, Nomor 1, Juli 2020

tempat itu terdapat kebun dengan tanamannya yang hidup dengan subur, tersedia rizki yang melimpah, terpenuhi kebutuhan hidup masyarakatnya. Negeri yang indah itu merupakan wujud kasih sayang Allah SWT yang disediakan bagi masyarakat Saba'. Allah SWT juga Maha Pengampun apabila terjadi kealpaan pada masyarakat tersebut. Karena itu Allah memerintahkan masyarakat Saba' untuk bersyukur kepada Allah yang telah menyediakan segala kebutuhan hidup mereka. Kisah keadaan masyarakat Saba' ini begitu populer dengan ungkapan Al Qur'an : Baldah thayyibah wa rabb ghafur. ${ }^{22}$

Meskipun ada yang beberapa tanggapan yang menolak contoh negeri Saba' sebagai simbol Baldah Thayyibah karena negeri itu pada akhirnya mengalami kehancuran karena ingkar (kafir) dan maksiat kepada Allah. Sehingga akhirnya mereka mendapat murka Allah dengan mengalami kebinasaan. Sekalipun bantahan tadi memang mengandung kebenaran, tetapi itu tidak menghapus berlakunya konsep Baldah Thayyibah. Yang mana pada dasarnya sejarah telah mencatat bahwa memang telah ada yang namanya Baldah Thayyibah meskipun pada akhirnya harus musnah.

Kedua, Masyarakat Yatsrib (Madinah). Masyarakat Yatsrib terdokumentasi sebagai masyarakat madani setelah terjadinya traktat/Piagam Madinah. Secara faktual, sebagai cerminan masyarakat yang ideal, kita dapat meneladani perjuangan Rasulullah mendirikan dan menumbuhkembangkan konsep masyarakat madani di Madinah. Prinsip terciptanya masyarakat madani bermula sejak hijrahnya Nabi Muhammad SAW dari Makkah ke Yatsrib (yang kemudian beliau mengganti namanya menjadi Madinah). Hal tersebut terlihat dari tujuan hijrah sebagai sebuah refleksi gerakan penyelamatan akidah dan sikap optimisme dalam mewujudkan cita-cita membentuk masyarakat yang madaniyyah (beradab). ${ }^{23}$

Sebelum dikuasai oleh masyarakat Arab Islam, penduduk Yatsrib terdiri dari dua suku dominan, yaitu Arab dan Yahudi. Suku-suku Yahudi terkemuka di sana adalah Bani Quraizah, Bani Nadir, dan Bani Qainuqa. Mereka membangun permukiman, pusat-pusat kegiatan ekonomi, dan benteng-benteng pertahanan. Atas upaya mereka, secara bertahap, Yatsrib menjadi kota penting. Sementara itu penduduk Arab berasal dari suku Aus dan Khazraj. ${ }^{24}$ Suku-suku di Yatsrib tidak mengenal persatuan. Kehidupan bermasyarakat kota Yatsrib selalu diwarnai oleh ketegangan

${ }^{22}$ M. Dawam Raharjo, Masyarakat Madani: Agama, Kelas Menengah dan..., hal. 82.

${ }^{23}$ Ismatul Izzah, "Peran Pendidikan Agama Islam dalam Membentuk Masyarakat Madani”, Jurnal Pedagogik, Vol. 05 No. 01, Januari-Juni 2018, hal. 59.

${ }^{24}$ Karen Amstrong, Muhammad Prophet For Our Time, terj. Yuliani Liputo, (Jakarta : Mizan, 2007), hal. 154. 
MA'ALIM: Jurnal Pendidikan Islam

Volume 1, Nomor 1, Juli 2020

bahkan peperangan, baik intern antar bangsa arab, atau antar yahudi. ${ }^{25}$ Fanatisme kesukuan dan ambisi kepemimpinan menjadi faktor utama terjadinya pertikaian dan peperangan di Yatsrib. Masing-masing suku dipimpin oleh kepala suku yang memikirkan kepentingan sukunya sendiri. Ini mengakibatkan terjadinya persaingan untuk memperoleh pengaruh yang besar di wilayah tersebut. Dari segi ekonomi dan politik, masyarakat Yahudi Yatsrib tergolong yang paling kuat. Tanah-tanah subur berada di bawah kekuasaan mereka. Dari segi jumlah pun, masyarakat Yahudi lebih banyak daripada suku-suku Arab. Pada sekitar tahun 610 hingga 620 M, ketegangan antara suku-suku Arab dan Yahudi meningkat tajam. Peperangan terbesar terjadi pada tahun 618 yang dikenal dengan Perang Bu'as. Peperangan tersebut menyadarkan orang-orang Arab bahwa peperangan justru membawa kerugian, sehingga suku Aus dan Khazraj bersatu.

Perselisihan yang terus menerus terjadi menimbulkan kesadaran di antara suku Aus dan Khazraj akan kebutuhan terhadap pemimpin yang dapat mengakomodir seluruh kepentingan masyarakat yang dikenal plural tersebut. Pada tahun $621 \mathrm{M}$, sebanyak 10 orang suku Khazraj dan dua orang suku Aus menemui Rasulullah di Makkah dan melakukan bai'at yang pertama yang disebut Bai'atul 'Aqabah Ula. ${ }^{26}$ Kemudian pada tahun $622 \mathrm{M}, 75$ orang penduduk Yasrib melakukan bait yang kedua. ${ }^{27}$ Kedua suku tersebut memandang Rasulullah sebagai sosok yang diyakini dapat mewujudkan perdamaian. Di samping itu, mereka juga mengetahui bahwa Rasulullah mendapat banyak ancaman di Makkah, akhirnnya mereka pun meminta Rasulullah agar berhijrah ke kota mereka. Atas permintaan tersebut, pada hari Senin, 22 September 622 M, Rasulullah beserta pengikutnya berangsur-angsur hijrah ke Madinah. Nabi dalam perjalanan hijrahnya ke Madinah, singgah di Quba, disana beliau dan para sahabatnya membangun masjid

25 John L. Esposito, Islam dan Politik, terj. Joesoeb Souyb, (Jakarta: Bulan Bintang, 1990), Hal. 7.

${ }^{26}$ Bai'at 'Aqabah Ula $(\underline{621 \mathrm{M}})$ adalah perjanjian Nabi Muhammad Sallallahu'Alaihi Wasallam dengan 12 orang dari Yatsrib yang kemudian mereka memeluk Islam. Bai'at 'Aqabah ini terjadi pada tahun kedua belas kenabiannya. Kemudian mereka berbaiat (bersumpah setia) kepada Muhammad. Isi baiat itu ada tiga perkara:

- Tidak menyekutukan Allah SWT dengan sesuatu apapun.

- Melaksanakan apa yang Allah perintahkan.

- Meninggalkan apa yang Allah larang.

${ }^{27}$ Bai'at 'Aqabah II ( $\left.\underline{622 \mathrm{M}}\right)$ adalah perjanjian yang dilakukan oleh Nabi terhadap 73 orang pria dan 2 orang wanita dari Yatsrib pada waktu tengah malam. Perjanjian ini terjadi pada tahun ketiga belas kenabian. Isi baiatnya adalah:

- Untuk mendengar dan taat, baik dalam perkara yang mereka sukai maupun yang mereka benci.

- Untuk berinfak baik dalam keadaan sempit maupun lapang.

- Untuk beramar ma'ruf nahi munkar.

- Agar mereka tidak terpengaruh celaan orang-orang yang mencela di jalan Allah.

- Agar mereka melindungi Muhammad sebagaimana mereka melindungi wanita-wanita dan anak-anak mereka sendiri. 
MA'ALIM: Jurnal Pendidikan Islam

Volume 1, Nomor 1, Juli 2020

Quba, yang kemudian dikenal dengan masjid an-Nabawi, bersamaan dengan pembangunan masjid, Rasul juga mempersaudarakan sahabat anshar (Mekah) dan muhajirin (Madinah). Inilah pilar yang melandasi proses pembentukan masyarakat madinah yang mempersaudarakan pengungsi dari Mekkah dengan penduduk asli Madinah.

Selang dua tahun pasca hijrah atau tepatnya 624 M, setelah Rasulullah mempelajari karakteristik dan struktur masyarakat di Madinah yang cukup plural, beliau kemudian melakukan beberapa perubahan sosial. Salah satu di antaranya adalah mengikat perjanjian solidaritas untuk membangun dan mempertahankan sistem sosial yang baru. Perjanjian itu dapat disebut sebagai suatu social society oleh para orientalis. Itulah sebabnya maka perjanjian tersebut dalam konteks teori politik disebut sebagai Piagam Madinah atau konstitusi Madinah (Mitsaq al-Madinah), karena di dalamnya memang terdapat pasal-pasal yang menjadi dasar hukum sebuah negara, yakni negara kota yang kemudian disebut Madinah, lengkapnya al-Madinah al-Munawwarah artinya Kota nan bercahaya. ${ }^{28}$

Posisi piagam Madinah adalah sebagai kontrak sosial antara Rasulullah dengan rakyat Madinah yang terdiri dari orang-orang Quraisy, kaum Yatsrib dan orang-orang yang mengakui dan berjuang bersama mereka. Piagam Madinah berisi rumusan yang jelas tentang hak-hak dan kewajiban orang Islam di antara mereka sendiri, serta hak-hak dan kewajiban di antara orang Islam dan Yahudi. Orang Yahudi menerima perjanjian tersebut dengan tangan terbuka dan penuh suka cita. Perjanjian Madinah berisi tentang kesepakatan ketiga unsur masyarakat untuk saling tolong menolong, menjadikan al-Qur'an sebagai pedoman dan konstitusi, menjadikan kedamaian dalam kehidupan sosial, menjadikan Rasulullah sebagai pemimpin, dan memberi kebebasan bagi penduduknya untuk memeluk agama serta beribadah sesuai dengan ajaran-ajaran agama yang dianutnya.

Menurut Nurcholis Madjid, realisasi masyarakat madani warisan Nabi yang terpancar dari nilai-nilai yang tertuang dalam Piagam Madinah memiliki enam ciri utama. Pertama, egalitarianisme. Dalam Piagam Madinah, terlihat betapa Islam memberikan jaminan kesamaan derajat warga negara ketika Islam secara adil mengatur pemenuhan hak-hak dan kewajiban warganya dan orang-orang yang terikat perjanjian dengan Rasulullah sebagai pemimpin masa itu. Egalitarianisme Islam menyangkut rasa keadilan, keberadaan, kerakyatan dan persamaan, prinsip musyawarah (demokrasi partisipatif), hikmat (wisdom), dan rasa perwakilan

\footnotetext{
${ }^{28}$ M. Dawam Raharjo, Masyarakat Madani: Agama, Kelas Menengah dan..., hal. 137.
} 
MA'ALIM: Jurnal Pendidikan Islam

Volume 1, Nomor 1, Juli 2020

(representativeness). ${ }^{29}$ Kedua, penghargaan kepada orang berdasarkan prestasi, bukan berdasarkan prestise keturunan, kesukuan, ras dan sebagainya. Hal ini memandang bahwa siapapun berhak mendapatkan penghargaan atas dedikasi yang telah dilakukan seseorang tanpa melihat nasab, keturunan, ras maupun agamanya. Ketiga, keterbukaan. Keterbukaan yaitu kesediaan menerima dan mengambil nilai-nilai (duniawi) yang mengandung kebenaran. Sikap terbuka akan menumbuhkan kesadaran sebagai sesama manusia dan sesama makhluk akan menumbuhkan rasa saling menghargai dan menghormati pada diri seseorang, berbentuk hubungan sosial yang saling mengingatkan tentang apa yang benar, tanpa memaksakan kehendak pribadi. ${ }^{30}$

Keempat, penegakan hukum dan keadilan. Hal ini cukup jelas dan tercantum dalam Piagam Madinah yang berbunyi "Bahwa orang-orang yang beriman dan bertaqwa harus melawan orang yang melakukan kejahatan di antara mereka sendiri, atau orang yang suka melakukan perbuatan aniaya, kejahatan, permusuhan atau berbuat kerusakan diantara orang-orang beriman sendiri dan mereka harus bersama-sama melawannya walaupun terhadap anak sendiri". Keadilan ini menunjuk pada sikap seimbang dan menengahi (fair dealing) dalam semangat moderniasasi dan toleransi. Dengan sikap berkeseimbangan tersebut, kesaksian dapat diberikan dengan adil, karena dilakukan dengan pikiran tenang dan bebas dari sikap berlebihan. Seorang saksi tidak bisa mementingkan diri sendiri, melainkan dengan pengetahuan yang tepat mengenai suatu persoalan dan mampu menawarkan keadilan. ${ }^{31}$

Kelima, Toleransi dan Pluralitas. Toleransi dan pluralitas tidak lain adalah wujud civility yaitu sikap kejiwaan pribadi dan sosial yang bersedia melihat diri sendiri tidak selalu benar. Pluralitas dan toleransi ini merupakan wujud dari ikatan keadaban (bound of civility), berarti masing-masing pribadi dan kelompok dalam lingkungan yang lebih luas, memandang yang lain dengan penghargaan, betapapun perbedaan ada tanpa saling memaksakan kehendak, pendapat atau pandangan sendiri.

Keenam, musyawarah. Musyawarah bersamaan dengan toleransi dan pluralitas merupakan demokrasi yang sebenarnya yang menjadi unsur asasi dari masyarakat madani. ${ }^{32}$ Menurut Nurcholis Madjid, Civil Society merupakan simbol masyarakat yang demokratis yang terbangun

${ }^{29}$ Nurcholish Madjid, Islam, Kemodernan, dan Keindonesiaan, Cet. XI (Bandung: Mizan, 1998), hal. 73-74.

${ }^{30}$ Nurcholish Madjid, Islam, Doktrin dan Peradaban; Sebuah Telaah Kritis Tentang Masalah Keimanan, Kemanusiaan, dan Kemodernan, Cet. IV (Jakarta: Paramadina, 2000), hal. 117.

${ }^{31}$ Ibid., hal. 116.

${ }^{32}$ Imam Sukardi, Islam dan Civil Society, Jurnal Tsaqafah Vol. 6 No. 1 Tahun 2010, hal. 123. 
MA'ALIM: Jurnal Pendidikan Islam

Volume 1, Nomor 1, Juli 2020

dengan menegakkan musyarawarah. Musyawarah pada hakekatnya adalah interpretasi positif berbagai individu dalam masyarakat yang saling memberikan hak untuk menyatakan pendapat, dan mengakui adanya kewajiban mendengar pendapat tersebut. Dalam proses musyawarah muncul hubungan sosial yang luhur dilandasi toleransi dan pluralitas.

Oleh karena itu, Robert N. Bellah seorang ahli sosiologi agama terkemuka menyebut masyarakat madani yang dibangun Rasulullah sebagai masyarakat yang sangat modern di zamannya, bahkan terlalu modern. Masyarakat Arab di bawah kepemimpinan Rasulullah telah melakukan lompatan jauh ke depan dalam kecanggihan sosial dan kapasitas politik. Sehingga setelah Rasulullah sendiri wafat kondisi ini tidak bisa bertahan lama. Timur Tengah pada saat itu belum siap dengan prasarana sosial yang diperlukan untuk menopang suatu tatanan sosial modern yang dirintis Rasulullah. ${ }^{33}$

\section{PENDIDIKAN ISLAM SEBAGAI WADAH PEMBENTUKAN MASYARAKAT MADANI}

Membangun masyarakat madani agar terbentuk karakteristik sebagaimana tersebut dalam beberapa penjelasan di atas, tidaklah semudah membalikkan telapak tangan. Inti dari terbentuknya masyarakat madani ialah lahirnya masyarakat yang seluruh aspek kehidupannya didasarkan pada nila-nilai ilahiyah yang bersifat universal. Sesungguhnya untuk mewujudkan keadaan masyarakat yang demikian maka salah satunya adalah dapat dicapai melalui pendidikan Islam, karena pendidikan Islam dengan berbagai aspeknya didasarkan pada nilai-nilai yang luhur dan universal. Paradigma pendidikan Islam pada hakekatnya adalah proses penanaman dan pewarisan nilai-nilai budaya Islam untuk memperdayakan dan atau mengembangkan potensi, serta sekaligus proses produksi nilai-nilai budaya Islam baru sebagai hasil interaksi potensi dengan lingkungan zaman yang terus maju ke depan dan berkembang dalam setiap lini kehidupan. Oleh karena itu, kunci keberhasilan umat Islam agar mampu menangkap ruh ajaran Islam yang sesungguhnya dan selalu konteks dengan kehidupan adalah melalui proses pendidikan. Fazlur Rahman mengatakan bahwa setiap reformasi dan pembaharuan dalam Islam harus dimulai dengan pendidikan. ${ }^{34}$ Mastuhu juga berpendapat bahwa manusia adalah makhluk yang memiliki daya akal dan kehidupan, maka ia harus membentuk peradaban dan memajukan kehidupan melalui proses pendidikan. ${ }^{35}$

\footnotetext{
${ }^{33}$ Robert N Bellah, Ed., Beyond Belief, (New York: Harper And Row, Edisi Paperblack, 1976), hal. 150-151, dalam Nurcholish Madjid, Islam, Kemodernan, dan Keindonesiaan, Cet. XI (Bandung: Mizan, 1998), hal. 38.

${ }^{34}$ Fazlur Rahman, Islam, terj.Ahsin Muhammad, (Bandung: Pustaka, 2003), hal. 44-46.

${ }^{35}$ Mastuhu, Dinamika Sistem Pendidikan Pesantren, Seri XX, (Jakarta: INIS, 1994), hal. 4.
} 
MA'ALIM: Jurnal Pendidikan Islam

Volume 1, Nomor 1, Juli 2020

Pendidikan Islam dengan istilah Islamic Studies, secara sederhana dikatakan sebagai usaha untuk mempelajari hal-hal yang berhubungan dengan agama Islam. Dengan perkataan lain usaha sadar dan sistematis untuk mengetahui dan memahami serta membahas secara mendalam tentang seluk beluk yang berhubungan dengan agama Islam, baik berhubungan dengan ajaran, sejarah maupun praktik-praktik pelaksanaannya secara nyata dalam kehidupan sehari-hari. Metodemetode dalam pendidikan Islam bukan hanya transformasi ilmu pengetahuan, tetapi juga meningkatkan dan meninggikan moral/akhlak. ${ }^{36}$

Beberapa pakar pendidikan Islam merumuskan beberapa pengertian pendidikan Islam. Muhammad Fadhil Al-Jamaly mendefinisikan pendidikan Islam sebagai upaya mengembangkan serta mengajak peserta didik lebih dinamis dengan berdasarkan nilai-nilai yang tinggi untuk kehidupan yang mulia. Dengan proses tersebut diharapkan akan terbentuk pribadi peserta didik yang sempurna, baik berkaitan dengan potensi akal, perasaan maupun perbuatannya. ${ }^{37}$ Sementara Al-Syaibaniy berpendapat pendidikan Islam adalah proses mengubah perilaku individu peserta didik pada kehidupan pribadi, masyarakat dan alam sekitarnya. Proses tersebut dilakukan dengan cara pendidikan dan pengajaran sebagai suatu aktivitas asasi dan profesi di antara sekian banyak profesi dalam masyarakat. Sedangkan Ahmad Tafsir mengartikan pendidikan Islam sebagai bimbingan yang diberikan oleh seseorang agar ia berkembang secara maksimal sesuai dengan ajaran Islam. ${ }^{38}$ Pendapat lain juga dikemukakan oleh Ahmad Marimba, bahwa pendidikan Islam adalah bimbingan atau pemimpin secara sadar oleh pendidik terhadap perkembangan jasmani dan rohani peserta didik menuju terbentuknya kepribadiannya insan kamil. ${ }^{39}$ Dari beberapa pengertian tersebut dapat disimpulkan bahwa pendidikan Islam sebagai sistem yang memungkinkan seseorang peserta didik, untuk mengarahkan kehidupannya sesuai dengan ideologi Islam. Melalui pendekatan ini, peserta didik akan dapat dengan mudah membentuk kehidupan dirinya sendiri sesuai dengan nilai-nilai ajaran islam yang diyakininya sehingga akan terbentuk kepribadian yang utama yakni Insan Kamil.

Pendidikan Islam bukan sekedar transfer of knowledge ataupun transfer of training, akan tetapi lebih merupakan suatu sistem yang ditata di atas pondasi keimanan dan kesalehan, yaitu

${ }^{36}$ M. Bali, Perguruan Tinggi Islam Berbasis Pondok Pesantren. (Malang: Al-Tanzim, 2017), hal. 2.

${ }^{37}$ Muhammad Fadhil Al-Jamaly, Nahwa Tarbiyat Mukminat, (Tunisia: al-syirkat al-Tunisiyat li al-Tauzi' 1977), hal. 4.

${ }^{38}$ Ahmad Tafsir, Ilmu Pendidikan dalam Perspektif Islam, (Bandung: Remaja Rosdakarya, 1992), hal. 3.

${ }^{39}$ Ahmad D. Marimba, Pengantar Filsafat Pendidikan Islam, (Bandung: Al-Ma'arif, 1989), hal. 2 
MA'ALIM: Jurnal Pendidikan Islam

Volume 1, Nomor 1, Juli 2020

suatu sistem yang terkait secara langsung dengan Tuhan. ${ }^{40}$ Dengan demikian, dapat dikatakan pendidikan Islam adalah suatu kegiatan yang mengarahkan dengan sengaja perkembangan seseorang sesuai atau sejalan dengan nilai-nilai Islam tentang manusia baik hakekat maupun sifatsifatnya, misi dan tujuan hidupnya di dunia dan akhirat kelak, hak dan kewajibannya sebagai individu dan anggota masyarakat yang diharapkan dapat membawa manusia ke arah kebahagiaan dunia dan akhirat melalui ilmu dan ibadah.

Sejalan dengan hal tersebut, membangun manusia yang bermoral dan beradab sama dengan membangun kualitas bangsa. Hal tersebut telah disepakati bahwa proses pembangunan suatu bangsa sangat bergantung terhadap sumber daya manusia yang ada. John Gardner mengatakan bahwa suatu bangsa akan menjadi besar apabila bangsa itu percaya pada sesuatu, dan sesuatu itu harus berdimensi moral, sesuatu itu tidak lain adalah agama. Agama akan membentuk manusia bermoral apabila dilakukan melalui jalur proses pendidikan. Seperti halnya pendidikan Islam di Indonesia sebagai sub sistem pendidikan nasional, pada hakekatnya juga bertujuan untuk berpartisipasi dalam membangun kualitas bangsa dalam segala aspeknya, terutama dalam hal peningkatan moral. ${ }^{41}$

\section{REFORMASI PENDIDIKAN ISLAM SEBAGAI KUNCI PEMBENTUKAN MASYARAKAT MADANI}

Dalam membangun masyarakat madani, pendidikan Islam dapat diibaratkan sebagai 'mesin' yang seharusnya bisa bekerja dengan baik sesuai standar yang telah ditentukan sehingga dapat berhasil guna menciptakan produk berupa masyarakat madani. Namun pada kenyataanya, pendidikan Islam masih menghadapi berbagai masalah dalam berbagai aspek. Pengembangan dan peningkatan pendidikan Islam sering bersifat sepotong-potong atau tidak komprehensif. Upaya perbaikannya belum dilakukan secara mendasar, sehingga terkesan seadanya saja. Selama ini upaya pembaharuan pendidikan Islam secara mendasar selalu dihambat oleh berbagai masalah mulai dari persoalan dana sampai tenaga ahli. Padahal pendidikan Islam dewasa ini, dari berbagai

${ }^{40}$ Roihan Achwan, Prinsip-Prinsip Pendidikan Islam Versi Mursi, Jurnal Ilmu Pendidikan Islam, Vol. 1 Tahun 1991, hal. 50.

${ }^{41}$ Nurcholish Madjid, Islam, Doktrin dan ..., hal. 20. 
MA'ALIM: Jurnal Pendidikan Islam

Volume 1, Nomor 1, Juli 2020

segi terlihat goyah terutama karena orientasi yang masih kurang jelas. ${ }^{42}$ Sistem pendidikan Islam tetap lebih cenderung berorientasi ke masa silam daripada ke masa depan. ${ }^{43}$

Berdasarkan uraian di atas, terdapat alasan pokok mengapa konsep pembaharuan pendidikan Islam untuk menuju masyarakat madani sangat mendesak. Pertama, konsep dan praktek pendidikan Islam dirasakan terlalu sempit, artinya terlalu menekankan pada kepentingan akhirat, sedangkan ajaran Islam menekankan pada keseimbangan antara kepentingan dunia dan akhirat. Maka perlu pemikiran kembali konsep pendidikan Islam yang betul-betul didasarkan pada asumsi dasar tentang manusia yang akan diproses menuju masyarakat madani. Kedua, lembagalembaga pendidikan Islam yang dimiliki sekarang ini, belum atau kurang mampu memenuhi kebutuhan umat Islam dalam menghadapi tantangan dunia modern di segala bidang. Hal tersebut antara lain disebabkan oleh beberapa faktor antara lain: a) rendahnya citra lembaga dan kualitas pendidikan Islam yang relatif rendah, b) kualitas dan kuantitas guru yang belum memadai, c) gaji guru secara umum masih kecil dan, e) tuntutan kompetisi dan kompetensi yang semakin meningkat.

Keberlangsungan pendidikan Islam bertumpu pada kemampuan menjawab berbagai tantangan yang terjadi. Hal ini bahkan dapat membuka peluang yang besar prospek pendidikan Islam di masa depan. Peluang tersebut dimungkinkan dan didukung oleh sejumlah kondisi sebagi berikut: 1) Potret masyarakat Indonesia adalah agamis. Kondisi semacam ini merupakan pondasi yang cukup kokoh bagi kehidupan lembaga pendidikan Islam, karena keinginan masyarakat yang cukup kuat untuk memiliki anak yang selain berilmu juga taat beragama. 2) Meningkatkan kesadaran beragama di kalangan masyarakat yang semula dikategorikan sebagai Islam formal. Peningkatan kesadaran beragama tersebut dengan sendirinya diikuti dengan meningkatnya kebutuhan akan pendidikan Islam bagi anak-anak mereka. 3) Pendidikan Islam, posisi madrasah yang semakin mantap seiring dengan lahirnya Undang-Undang No. 20 Tahun 2003 tentang Sistem Pendidikan Nasional. Dalam undang-undang tersebut pendidikan seperti madrasah diakui sebagai bagian dari sistem pendidikan nasional. 4) Keimanan dan ketaqwaan semakin menempati posisi yang setrategis dalam kehidupan berbangsa dan bernegara. Dengan kata lain, setiap langkah pembangunan bangsa harus dijiwai oleh nilai-nilai agama. 5) Meningkatnya status sosial-politik

\footnotetext{
${ }^{42}$ Muslih Usa, Pendidikan Islam di Indonesia antara Cita dan Fakta, Cet. I, (Yogyakarta: Tiara Wacana, Yogyakarta, 1991), hal. 11-13.

${ }^{43}$ Azyumardi Azra, Menuju Masyarakat Madani, Gagasan, Fakta, dan Tantangan, (Bandung: PT. Remaja Rosdakarya, 1999), hal. 59.
} 
MA'ALIM: Jurnal Pendidikan Islam

Volume 1, Nomor 1, Juli 2020

kalangan santri pada masa ini banyak sekali elit politik, birokrat maupun tokoh masyarakat yang berasal dari kalangan santri. Hal ini secara tidak langsung juga berdampak positif bagi meningakatnya perhatian dan penghargaan terhadap lembaga pendidikan Islam. 6) Meningkatnya kualitas pendidikan Islam, seperti madrasah dan sekolah Islam berkualitas rendah, namun beberapa madrasah ternyata mengungguli lembaga pendidikan atau sekolah umum. ${ }^{44}$

Peluang-peluang seperti yang telah disebutkan di atas harus dimanfaatkan sebaik mungkin untuk melakukan reformasi/pembaharuan pendidikan Islam. Pendidikan Islam harus didesain mampu untuk menjawab perubahan menuju ke arah masyarakat madani dengan meningkatkan mutu umatnya. Menurut Baharuddin, untuk dapat meningkatkan mutu masyarakat, pendidikan Islam hendaknya dapat melakukan reformasi sebagai berikut: a) agama yang disajikan dalam proses pendidikan harus lebih lebih menekankan kepada kesalehan aktual bukan semata-mata kesalehan ritual. Hal ini penting ditekankan mengingat millennium ketiga akan semakin diwarnai selain oleh trust juga oleh kompetisi, b) pendidikan Islam harus mempunyai generasi terdidik yang pluralis yang mampu menghadapi kemajemukan baik internal maupun eksternal, c) pengembangan sifat pluralis tersebut harus merupakan bagian tak terpisahkan dari upaya besar mewujudkan masyarakat madani yang demokratis, terbuka dan beradab yang menghargai perbedaan pendapat. Justru selalu diupayakan sebagai rahmat bukan sebagai laknat, d) masyarakat madani yang diharapkan adalah masyarakat yang penuh percaya diri, memiliki kemandirian dan kreatifitas yang tinggi dalam memecahkan masslah yang diahadapi, e) pendidikan yang dilakukan harus menyiapkan generasi yang siap berpartisipasi aktif dalam interaksi global. Oleh karena itu, pengetahuan dan keterampilan yang diberikan harus memiliki relevansi yang kuat dengan trend globalisasi. $^{45}$

Usulan perubahan juga dikemukakan oleh Suroyo, antara lain: (a) pendidikan harus menuju pada integritas antara ilmu agama dan ilmu umum untuk tidak melahirkan jurang pemisah antara ilmu agama dan ilmu bukan agama, karena, dalam pandangan seorang muslim, ilmu pengetahuan adalah satu yaitu yang berasal dari Allah SWT, (b) pendidikan hendaknya menuju tercapainya sikap dan perilaku toleransi, lapang dada dalam berbagai hal, terutama toleran dalam perbedaan pendapat dan penafsiran ajaran Islam, tanpa melepaskan pendapat atau prinsip yang diyakini, (c)

\footnotetext{
${ }^{44}$ A. Fauzi, Membangun Epistemologi Pendidikan Islam Melalui Kepemimpinan Spiritual : Suatu Telaah Diskursif, (Kediri: Empirisma, 2015), hal. 155.

${ }^{45}$ Baharuddin dkk., Dikotomi Pendidikan Islam: Historisitas dan Implikasi Pada Masyarakat Islam. (Bandung: PT Remaja Rosdakarya, 2011), hal. 23.
} 
MA'ALIM: Jurnal Pendidikan Islam

Volume 1, Nomor 1, Juli 2020

pendidikan hendaknya mampu menumbuhkan kemampuan untuk berswadaya dan mandiri dalam kehidupan, (d) pendidikan hendaknya menumbuhkan ethos kerja, mempunyai aspirasi pada kerja, disiplin dan jujur, (e) pendidikan Islam harus didesain untuk mampu menjawab tantangan masyarakat madani. ${ }^{46}$

Hal-hal lain yang tidak kalah penting yang harus diperhatikan dalam reformasi pendidikan Islam yakni: a) peningkatan mutu sumber daya manusia, diantara tuntutan internal dan tantangan eksternal, maka keunggulan yang mutlak dimiliki oleh peserta didik adalah penguasaan atas sains dan teknologi dan keunggulan kualitas sumber daya manusia, b) menyiapkan kurikulum yang handal yang berwawasan masa kini dan masa depan. Kurikulum ini diharapkan dapat menciptakan manusia-manusia yang memiliki kemampuan yang berkualitas dan memiliki keterampilan dan kecakapan dalam hidup, c) Sarana dan prasarana yang memadai dan merupakan unsur penting yang sangat menunjang bagi kelancaran dan keberhasilan proses pendidikan. Oleh karena itu, sarana dan prasarana akademik mutlak perlu, baik berupa perpustakaan, gedung, pembelajaran, dan lain sebagainya, d) mendekonstruksi metode dan manajemen.Metodologi dan manjemen yang selama inikita pakai harus dirubah dan dibangun lagi yang baru, yang dapat membawa semangat dan konsep baru sehingga menghasilakn tujuan tersebut sesuai dengan masyakat modern, e) pengembangan ilmu sosial profetik. Ilmu sosial profetik adalah ilmu sosial yang dalam pengembangan ilmu, didasarkan dengan konsep keilahian.

Mencermati berbagai tantangan di atas, maka tidaklah mustahil pendidikan Islam dapat memainkan peran penting dan strategis dalam mewujudkan masyarakat madani. Karena bagaimanapun pendidikan Islam setidaknya memiliki dua misi yang harus diemban, yaitu pertama Menanamkan pemahaman Islam secara komperhensip agar peserta didik mampu mengetahui ilmuilmu Islam sekaligus mempunyai kesadaran untuk mengamalkannya. Pendidikan Islam tidak semata-mata mengajarkan pengetahuan Islam secara teoritik saja sehingga hanya menghasilkan seorang cendikiawan muslim, tetapi Islam juga menekankan pada pembentukan sikap dan prilaku yang islami dengan membentuk peserta didik menjadi Insan Kamil. Kedua, memberikan bekal kepada peserta didik agar nantinya dapat berkiprah dalam kehidupan masyarakat, serta survive menghadapi berbagai tantangan yang semakin tidak terkendali. ${ }^{47}$ Dengan dua misi di atas, maka

${ }^{46}$ Suroyo, Antisipasi Pendidikan Islam dan Perubahan Sosial Menjangkau Tahun 2000, dalam Muslih Usa, Pendidikan Islam di Indonesia antara Cita dan Fakta, (Yogyakarta: Tiara Wacana, 1991), hal. 45-46.

${ }^{47}$ Baharuddin dkk., Dikotomi Pendidikan Islam..., hal. 26. 
MA'ALIM: Jurnal Pendidikan Islam

Volume 1, Nomor 1, Juli 2020

tidaklah berlebihan bahwa pendidikan Islam memiliki peran penting dalam rangka mempersiapkan generasi muda yang tidak hanya memiliki kualitas intlektual yang tinggi, kepribadian yang tangguh, kreatifitas dan keterampilan yang memadai, melainkan juga yang sangat penting dan harus menjadi dasar yaitu memiliki akhlak dan budi pekerti serta iman yang kokoh dan kuat sehingga upaya dalam mewujudkan masyarakat madani bukan sekedar slogan belaka.

Jika dicermati dengan seksama, pendidikan Islam dan masyarakat madani memiliki keterkaitan yang erat antara keduanya. Pendidikan Islam bertujuan untuk menciptakan pribadipribadi yang bertaqwa, beretika-moral yang baik, yang dilandaskan pada ajaran-ajaran Islam yang bersumber dari al-Qur'an dan Hadits yang muara akhirnya adalah penciptaan manusia paripurna atau insan kamil. Sedangkan masyarakat madani (civil society) adalah kondisi di mana masyarakat mempunyai budi baik (beradab) yang dilandaskan sikap transcendental (berdasarkan agama) yang bersumber dari doktrin langit (wahyu/ajaran Tuhan). Secara sederhana, sangatlah jelas hubungan antara Pendidikan Islam dengan masyarakat madani (civil society), karena di satu sisi jika kita pahami bahwa Pendidikan Islam membentuk pribadi-pribadi yang beradab, maka hasilnya adalah terbentuknya masyarakat yang beradab pula. Setidaknya ada dua macam keterkaitan antara keduanya. Pertama, keterkaitan fungsional. Keterkaitan ini dimaksudkan bahwa antara pendidikan Islam dan masyarakat madani memiliki kesamaan fungsi, di mana pendidikan Islam sebagai (lembaga) pencetak individu-individu yang beradab (madani) yang notabene didambakan oleh masyarakat. Pendidikan Islam dapat berperan sebagai supplier tenaga ahli atau Sumber Daya Manusia yang bermoral, beradab dan beretika sosial (guru) yang berguna bagi masyarakat yang menjadi konsumen pendidikan, dan di satu sisi masyarakat juga bisa menjadi produsen dalam dunia pendidikan melalui sebuah lembaga pendidikan. Kedua, keterkaitan filosofis. Keterkaitan filosofis ini berbicara mengenai hakikat antara pendidikan Islam dan masyarakat madani. Pada hakikatnya, pendidikan Islam merupakan peradaban manusia. Dengan kata lain, proses pendidikan merupakan aktifitas yang dilakukan manusia dalam membangun peradaban. Maka secara filosofis, dalam membangun peradaban, manusia wajib berpegang teguh pada nilai-nilai yang ada dalam alQur'an dan hadits, yang mana nilai-nilai tersebut adalah ruh dari pendidikan Islam itu sendiri.

Keterkaitan antara pendidikan Islam dan masyarakat madani bukanlah sebuah kebetulan semata. Hal ini berarti bahwa salah satu tonggak berdirinya bangunan masyarakat madani yang kokoh dan tangguh terletak pada tegaknya kualitas Pendidikan Islam dalam sebuah masyarakat. 
MA'ALIM: Jurnal Pendidikan Islam

Volume 1, Nomor 1, Juli 2020

Keduanya hendaklah bersinergi antara satu dengan yang lain demi terwujudnya insan kamil dan baldah thayyibah wa rabb ghafur.

\section{KESIMPULAN}

Masyarakat madani merupakan sebuah keniscayaan bagi suatu bangsa. Masyarakat beradab yang selalu menjunjung tinggi moral dan akhlak mulia, mengedepankan sikap toleransi, penuh semangat pluralisme, mengutamakan kualitas baik di bidang ilmu pengetahuan maupun teknologi. Kualitas masyarakat yang demikian tidak akan pernah terwujud tanpa adanya pendidikan yang bersumber pada agama. Pendidikan Islam merupakan salah satu gerbang besar terbukanya konsep masyarakat madani dalam masyarakat. Pendidikan Islam menjadi pijakan utama dalam membentuk individu-individu bermoral, bermartabat, berakhlak mulia serta berethos kerja sesuai dengan tuntunan al-Qur'an dan hadits.

Oleh karena itu, dapat dinyatakan bahwa pendidikan islam yang baik dan berkualitas dapat berdaya guna dan berhasil guna dalam membangun masyarakat yang ber-tamaddun di segala bidang. Sehingga timbal baliknya, masyarakat yang madani dapat membuka berbagai peluang dan terobosan terhadap peningkatan kualitas pendidikan Islam secara signifikan dan berkesinambungan.

\section{DAFTAR PUSTAKA}

Achwan, Roihan. Prinsip-Prinsip Pendidikan Islam Versi Mursi dalam Jurnal Ilmu Pendidikan Islam, Vol. 1 Tahun 1991.

Amstrong, Karen. Muhammad Prophet For Our Time. terj. Yuliani Liputo. Jakarta : Mizan, 2007.

Azizi, A. Qodri Abdillah. "Masyarakat madani Antara Cita dan Fakta: Kajian Historis-Normatif" dalam Ismail SM dan Abdullah Mukti, Pendidikan Islam, Demokratisasi dan Masyarakat Madani. Yogyakarta: Pustaka Pelajar, 2000.

Azra, Azyumardi. Menuju Masyarakat Madani, Gagasan, Fakta, dan Tantangan. Bandung: PT. Remaja Rosdakarya, 1999.

Baharuddin dkk. Dikotomi Pendidikan Islam: Historisitas dan Implikasi Pada Masyarakat Islam. Bandung: PT Remaja Rosdakarya, 2011.

Bellah, Robert N, Ed. Beyond Belief. New York: Harper And Row, Edisi Paperblack, 1976. 
MA'ALIM: Jurnal Pendidikan Islam

Volume 1, Nomor 1, Juli 2020

Busyairi, Ahmad dan Azharuddin Sahil. Tantangan Pendidikan Islam. Yogyakarta: LPM UII, 1987.

Charis, Irfan dan Mohamad Nuryansah. "Pendidikan Islam Dalam Masyarakat Madani Indonesia” dalam Jurnal Mudarrisa: Jurnal Kajian Pendidikan Islam, Vol. 7 No. 2 Desember 2015.

Esposito, John L. Islam dan Politik. terj. Joesoeb Souyb. Jakarta: Bulan Bintang, 1990.

Fauzi, A. Membangun Epistemologi Pendidikan Islam Melalui Kepemimpinan Spiritual : Suatu Telaah Diskursif. Kediri: Empirisma, 2015.

Hamim, Thoha. Islam dan Civil Society (Masyarakat Madani). Yogyakarta: Pustaka Pelajar, 2000.

Izzah, Ismatul. "Peran Pendidikan Agama Islam dalam Membentuk Masyarakat Madani” dalam Jurnal Pedagogik, Vol. 05 No. 01, Januari-Juni 2018.

Luth, Thohir. Masyarakat Madani Solusi Damai Dalam Perbedaan. Jakarta: Mediacita, 2002.

Madjid, Nurcholish. Islam, Doktrin dan Peradaban; Sebuah Telaah Kritis Tentang Masalah Keimanan, Kemanusiaan, dan Kemodernan. Cet. IV. Jakarta: Paramadina, 2000. . Islam, Kemodernan, dan Keindonesiaan. Cet. XI. Bandung: Mizan, 1998.

. "Menuju Masyarakat Madani” dalam Jurnal Kebudayaan dan Peradaban Ulumul Qur'an, No. 2/VII/1996.

Malekian, Farhad. Corpus Juris of Islamic International Criminal Justice. Ukraina: Cambridge Scholars Publishing, 2017.

Marimba, Ahmad D. Pengantar Filsafat Pendidikan Islam. Bandung: Al-Ma'arif, 1989.

Mastuhu. Dinamika Sistem Pendidikan Pesantren. Seri XX. Jakarta: INIS, 1994.

Ma’arif, A. Syafi’I. Mencari Autentisitas Dalam Kegalauan. Yogyakarta: PSAP, 2004.

Muhammad Fadhil Al-Jamaly, Nahwa Tarbiyat Mukminat, Tunisia: al-syirkat al-Tunisiyat li alTauzi', 1977.

Muslih, Muhammad. "Wacana Masyarakat Madani: Dialektika Islam Dengan Problem Kebangsaan" dalam Jurnal Tsaqafah Vol. 6 No. I April 2010.

Nata, Abudin. Managemen Pendidikan: Mengatasi Kelemahan Pendidikan Islam. Jakarta: Prenada Media, 2003.

Raharjo, M. Dawam. Masyarakat Madani: Agama, Kelas Menengah dan Perubahan Sosial. Cet. I. Jakarta: Pustaka LP3ES, 1999.

."Masyarakat Madani di Indonesia Sebuah Penjajakan Awal”dalam Jurnal Pemikiran Islam Paramadina Jakarta, Vol. I No. 2, 1999. 
MA’ALIM: Jurnal Pendidikan Islam

Volume 1, Nomor 1, Juli 2020

. Sejarah Agama dan Masyarakat Madani dalam Membongkar "Mitos"

Masyarakat Madani. Yogyakarta: Pustaka Pelajar, 2001.

Rahman, Fazlur. Islam. terj.Ahsin Muhammad.Bandung: Pustaka, 2003.

Rosyada, Dede, et al. Pendidikan Kewarganegaraan (Civic Education), Demokrasi, Hak Asasi Manusia dan Masyarakat Madani. Jakarta: ICCE UIN Syarif Hidayatullah dan Prenada Media, 2003.

Rousseau, J.J. The Social Contract. translt. M. Cranston. Book IV. Harmondsworth: Penguin, 1968.

SM, Ismail dan Abdullah Mukti. Pendidikan Islam, Demokratisasi dan Masyarakat Madani. Yogyakarta: Pustaka Pelajar, 2000.

Sukardi, Imam. Islam dan Civil Society. Jurnal Tsaqafah Vol. 6 No. 1 Tahun 2010.

Suroyo. Antisipasi Pendidikan Islam dan Perubahan Sosial Menjangkau Tahun 2000, dalam Muslih Usa, Pendidikan Islam di Indonesia antara Cita dan Fakta. Yogyakarta: Tiara Wacana, 1991.

Tafsir, Ahmad. Ilmu Pendidikan dalam Perspektif Islam. Bandung: Remaja Rosdakarya, 1992.

Usa, Muslih. Pendidikan Islam di Indonesia antara Cita dan Fakta. Cet. I.Yogyakarta: Tiara Wacana, Yogyakarta, 1991. 